\title{
HOW DO REACTION TIME AND MOVEMENT SPEED DEPEND ON THE COMPLEXITY OF THE TASK?
}

\author{
Dalia Mickevičienė, Kristina Motiejūnaitė, Albertas Skurvydas, \\ Tomas Darbutas, Diana Karanauskienė \\ Lithuanian Academy of Physical Education, Kaunas, Lithuania
}

\begin{abstract}
Dalia Mickevičienė. PhD in Biomedical Sciences, Assoc. Professor at the Department of Applied Physiology and Sports Medicine, Lithuanian Academy of Physical Education. Research interests: complex and dynamic adaptation of motor system.
\end{abstract}

\begin{abstract}
The aim of the research was to determine how the reaction time and the movement speed depend on the complexity of the task.

The research was carried out in the Laboratory of Human Motor Control at the Lithuanian Academy of Physical Education (LAPE) applying the analyzer of dynamic parameters of human leg and arm movement (DPA-1; Patent No. 5251; 200508 25), which is used for the qualitative estimation of the dynamic parameters of one arm and leg target movement, two arms and legs coordinated and independent target movements, when the resistance power and target are coded with different programmable parameters. We registered the reaction time (RT) and the movement speed $\left(V_{\max }\right)$ performing simple tasks of reaction and speed and a complicated task of accuracy.

Research results indicated that performing a complicated task the reaction is slower, and the maximal movement speed is lower than performing a simple task. However, it does not mean that movement speed will be higher when the reaction is faster performing a simple task. The data obtained confirmed Hick's law proposing that reaction time is directly proportional to the complexity of the task because performing the tasks of different levels of complexity the reaction time values of the right arm were statistically significantly different $(p<0.001)$.

After performing the analysis of variation coefficients we established that the highest coefficient of variation was received from the indices of movement speed performing a speed task (23\%), and the lowest - of reaction time performing a reaction task (10\%). The obtained results confirm other authors'suggestion that performing a complicated task the reaction time is a more steadily controlled index than maximal movement speed.

A strong correlation was determined between the reaction time values performing the tasks of reaction and accuracy, but there was no statistical link between the maximal speed values performing the tasks of speed and accuracy. This indicates that if the movement speed is high performing a simple task, it does not mean that it will be high performing a complicated task.

Conclusions: 1) performing a complicated task reaction time is longer, and maximal movement speed is lower than performing a simple task; 2) the complexity of the task more impacts the dispersion of results of the movement speed than of the reaction time; 3) high speed performing a simple task does not indicate that it will be high performing a complicated task.
\end{abstract}

Keywords: reaction time, movement speed, the complexity of the task.

\section{INTRODUCTION}

$\mathrm{T}$ The system of human movement (motor system) depends on the complex, dynamic and adaptive systems (Kaplan, Glass, 1995; Kauffman, 1995; Latash, 1998; Kelso, 1999; Wolpert et al., 2001; Goldberger et al., 2002; Skurvydas, Mamkus, 2002; Newell, 2003). The dynamism of movements is an inevitable and essential peculiarity of movement performance, without which movements would lose their stability and adaptivity (Bernstein, 1967; Newell, Corcos, 1993;
Kelso, 1999; Davids et al., 2006). Thus, control of dynamic (constantly changing) movements is one of the greatest problems of motor control and motor learning (Scott, 2005).

Recently the scientists have been especially interested in the consisted patterns of motor behavior and the models of motor learning and motor control. There are many studies analyzing reaction time, speed and accuracy of movements as well as their interrelation (Schmidt, Lee, 1999; Fischer 
et al., 2007). Some researchers refer to Fitts's law which explains the dependence of the duration of rapid and accurate movement on the distance to the target and the size of the target (Plamondon, Alimi, 1997; Schmidt, Lee, 1999; Bootsma et al., 1994; Pratt et al., 2007), others invoke Hick's law which explains the dependence of the reaction time on the complexity of movement (Schmidt, Lee, 1999; Allen et al., 2004). We were unable to find studies analyzing Fitts's and Hick's laws together.

The aim of the research was to determine how the reaction time and the movement speed depend on the complexity of the task.

\section{RESEARCH METHODS}

Research participants were 20 healthy males and females involved and not involved in sports. Their age was $26.6 \pm 8.07$ years, body mass $-70.1 \pm 9.38 \mathrm{~kg}$, height $-177 \pm 6.81 \mathrm{~cm}$. The subjects were informed about the research procedures.

The research was carried out in the Laboratory of Human Motor Control at the Lithuanian Academy of Physical Education (LAPE) applying the analyzer of dynamic parameters of human leg and arm motion (DPA-1; Patent No. 5251; 20050825 ), which is used for the qualitative estimation of the dynamic parameters of one arm and leg target movement, two arms and legs coordinated and independent target movements, when the resistance power and target are coded with different programmable geometrical, chromatic and temporarily set parameters.

Analyzer DPA-1 measuring reaction time, movement speed and accuracy. The analyzer contains two measuring devices connected to a stationary standard computer with Windows (or compatible to it) operating environment, which has an imbedded measurement card with an operating system, and a 17' diameter screen. The measuring device includes:

- The mechanism for transforming handle movement into the measurement zone reduced six times;

- The mechanism for measuring the coordinates of handle movement;

- The mechanism for establishing the horizontal component of the module of strength impacting the handle with the strength measuring element;

- The electromagnetic mechanism for the development of strength of programmable resistance;

- The strength measuring unit;

- The control unit of programmable resistance strength;

- Power supply.

Measuring devices are fastened to the support panel where the handle units slide on its surface. The power supply switch with the power voltage indicators are fitted in the front of the measuring devices, the connectors for the power cable and the distance control are built-in in the back.

Methods of studying reaction time, movement speed and accuracy. During the research the participants are seated in a special chair at the table with a DPA-1 fastened on it. The subject's back is straight and leant at the backrest. Both arms are bent $90^{\circ}$ at the elbow joint so that the upper arms are nestled against the sides, and the forearms rest on the DPA-1 support panel. The legs are bent $90^{\circ}$ at

Figure 1. The analyzer of dynamic parameters of human leg and arm motion (DPA-1)

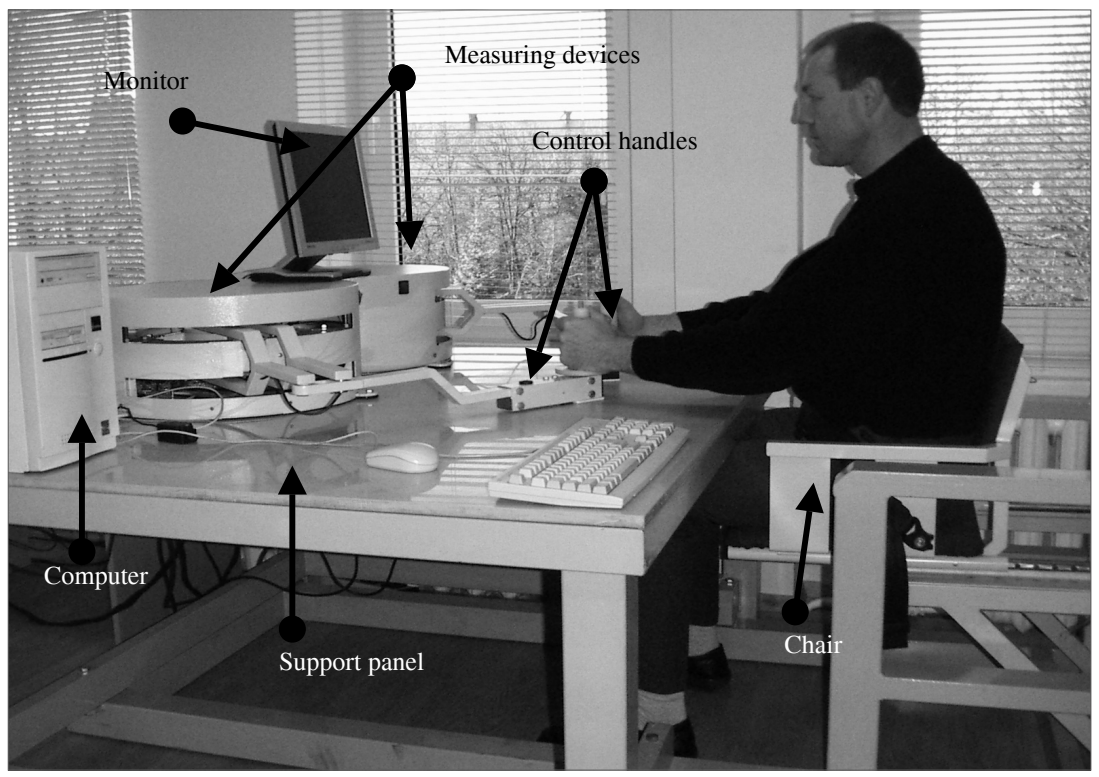


the knees and the feet rest on the floor. The position of the DPA-1 chair is regulated so that the subject could sit comfortably and take a standard position. The distance between the computer screen and the subject's eyes is approximately $70 \mathrm{~cm}$.

The subjects perform the tests with their right arm. In accordance with the tasks of the test prepared in advance, a target - a red circle $7 \mathrm{~mm}$ in diameter - appears on the screen at stated intervals. During each task the subject sets the handle symbol of $3.5 \mathrm{~mm}$ in diameter to the start zone (the center of a green circle the diameter of which is $10 \mathrm{~mm}$ ) on the computer screen. The program intermittently (every $1-3 \mathrm{~s}$ ) generates a sound signal and / or a target in the certain place on the computer screen, and the subject has to react to it pushing the handle the drag force of which equals to $20 \mathrm{~N}$. The distance between the centers of the start circle and the target circle is $170 \mathrm{~mm}$. The measurement cycle is completed after performing a movement or hitting the target (depending on the task). The information about the task performed is stored in the computer memory and later it is transferred to Microsoft Excel program.

Research procedures of the reaction time, movement speed and accuracy. The subjects performed three tasks: reaction, speed and accuracy. The reaction task was as follows: the subjects had to react as quickly as possible and to move the handle of the device. After explaining the task they were allowed to take three tries, the results of which were not recorded. Then the task was performed 20 times successively registering the reaction time (RT) of the right arm in ms.

After 5 minutes the subjects performed the speed task - as soon as they heard the sound signal, they had to stretch their right arm, holding the handle of the device, at the elbow joint as fast as they could. Three tries were allowed, and their results were not recorded. Then the task was repeated five times in success. We registered the maximal movement speed $\left(\mathrm{W}_{\max } ; \mathrm{mm} / \mathrm{s}\right)$ of the right arm.

The accuracy task was performed five minutes after the speed task. The subjects had to react to the target on the computer screen as fast as they could and to push the handle of the device so that the circle of the handle symbol reached the target as fast as possible and followed the most accurate trajectory, and then stopped in it. The target appeared in the same place. The end-point of the movement was recorded when the center of the handle symbol stopped in the circle and stayed there for no less then $0.03 \mathrm{~s}$. After explaining the task the subjects were allowed to take three tries, the results of which were not recorded. Then the task was performed 20 times in success. We registered the reaction time (RT-T) of the right hand (ms) and the maximal movement speed $\left(\mathrm{V}_{\max }-\mathrm{T}\right)(\mathrm{mm} / \mathrm{s})$.

After each repetition the subjects could see their achieved result on the computer screen, besides they were motivated verbally to do their best.

Methods of mathematical statistics. We calculated the values of arithmetic mean $(\bar{x})$, root mean square deviation $(\sigma)$, coefficient of variation $\left(\mathrm{V}_{\mathrm{A}} \%\right)$ and the Pearson correlation coefficient $(r)$ of the indicators produced by the subjects. Reliability of the sample differences was estimated applying Student's $t$ test.

\section{RESEARCH RESULTS}

We established statistically significant differences $(p<0.001)$ between the mean values of reaction time performing the tasks of reaction and accuracy, $237.8 \pm 22.9 \mathrm{~ms}$ and $321.1 \pm 52.0 \mathrm{~ms}$ respectively (Fig. 2).

The maximal movement speed of the right arm was statistically significantly $(\mathrm{p}<0.001)$ higher performing the speed task $(1513.3 \pm 342.8 \mathrm{~mm} / \mathrm{s})$ compared to the task of accuracy $(566.9 \pm 91.1 \mathrm{~mm} / \mathrm{s})$ (Fig. 3).

Aiming to estimate the dispersion of the indices in our study we calculated the coefficients of variation of different tasks. The least coefficient of variation was that of the reaction time performing a simple reaction task $(10 \%)$. The greatest coefficient of variation was the coefficient of maximal movement speed performing a simple speed task (23\%) (Table 1).

Table 2 includes the correlated links between the reaction time and the maximal speed performing the tasks of reaction, speed and accuracy.

The analysis of correlated links revealed a strong reciprocal statistical relation between the indices of reaction time and maximal speed movement $(-0.71)$ performing the task of "accuracy". We suggest that performing a complicated task the higher movement speed is produced by those subjects who faster respond to the stimulus. It is worth noting that performing a simple task the statistical link between those two indices was rather weak $(-0.23)$. The correlation between reaction times performing reaction and accuracy tasks was 0.56 , but no statistical link was found between the maximal speed values performing the speed and accuracy tasks $(-0.09)$. 
Figure 2. The mean values of reaction time (ms) performing the tasks of reaction (RT) and accuracy (RT-T)
Note. * $-\mathrm{p}<0.05$, comparing RT and RT-T results.

Figure 3. The mean values of maximal movement speed $(\mathrm{cm} / \mathrm{s})$ performing the tests of speed $\left(V_{\text {max }}\right)$ and accuracy $\left(V_{\max }-T\right)$
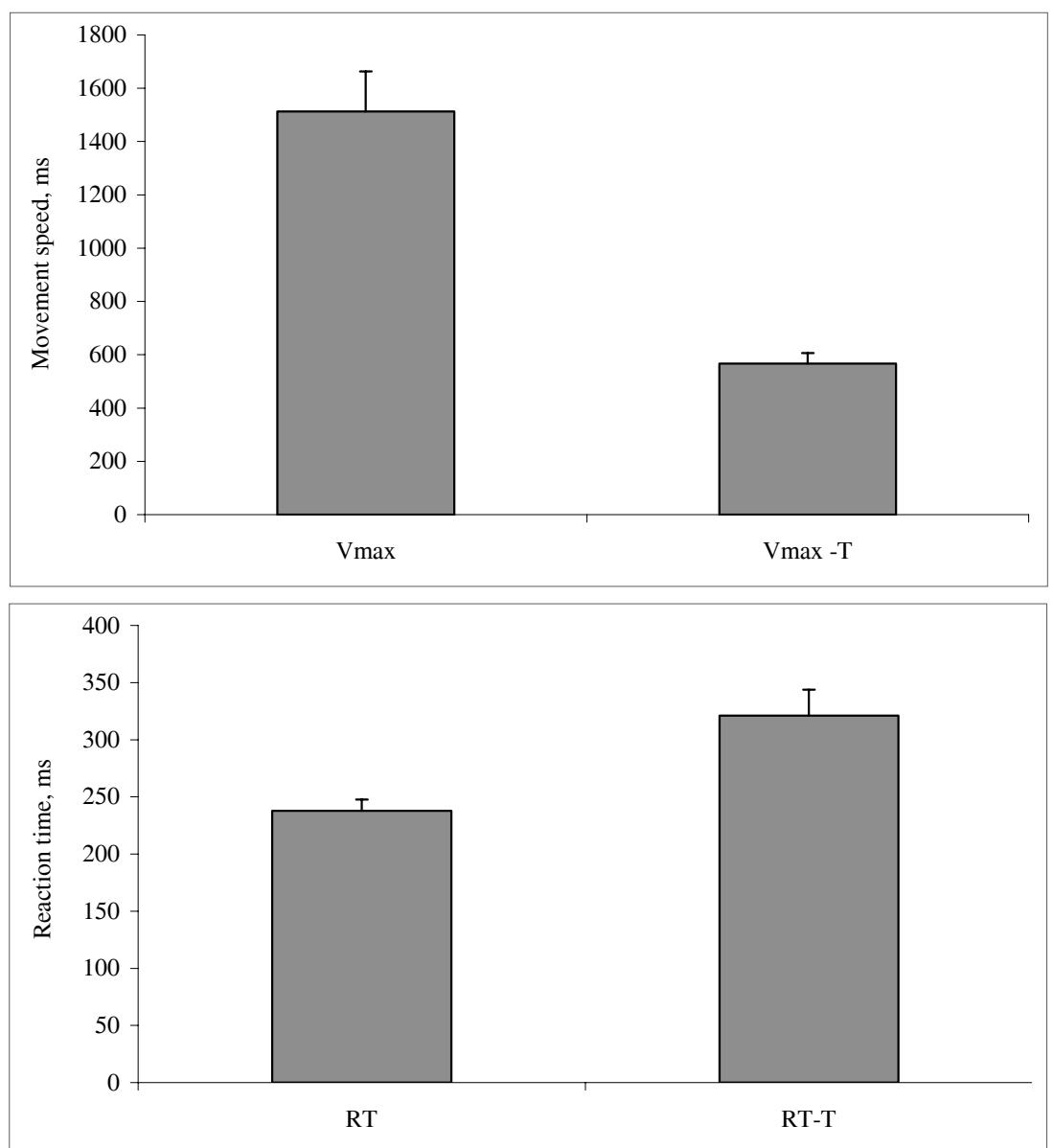

\begin{tabular}{|l|l|l|}
\hline Parameters & RT, $\%$ & $\mathbf{V}_{\text {max }}, \%$ \\
\hline Reaction task & 9.6 & - \\
\hline Speed task & - & 22.7 \\
\hline Accuracy task & 16.2 & 16.0 \\
\hline
\end{tabular}

Table 2. Correlation coefficients between the results of reaction, speed and accuracy tasks

\begin{tabular}{|l|l|l|l|l|}
\hline Parameters & RT & RT-T & $\mathbf{V}_{\max }$ & $\mathbf{V}_{\max }-\mathbf{T}$ \\
\hline RT & 1 & & & \\
\hline RT-T & 0.56 & 1 & & \\
\hline Vmax & -0.26 & -0.07 & 1 & \\
\hline Vmax-T & -0.23 & -0.71 & -0.09 & 1 \\
\hline
\end{tabular}

\section{DISCUSSION}

Answering the question how reaction time and movement speed depend on the complexity of the task we suggest that performing a complicated task the reaction is slower, and the maximal movement speed is lower than performing a simple task. However, it does not mean that the movement speed will be higher if the reaction is faster performing a simple task.

The obtained results confirm other researches proposition that the more complicated movement is needed to be planned, the longer is the time of planning that movement, which is indicated by the reaction time from the beginning of a stimulus till the beginning of the movement (Schmidt, Lee, 1999; Muckus, 2003). Research results indicated that performing the tasks of different levels of complexity the reaction time values of the right arm were statistically significantly different $(\mathrm{p}<0.001)$. This fact has confirmed Hick's law that reaction time is directly proportional to the complexity of the task (Jensen, 1998; Gignac, Vernon, 2004). However, research findings obtained by other authors have shown that the indices of the reaction time performing the tasks of different levels of complexity do not differ statistically significantly (Shen Yin-Chen, Franz, 2005). The 
authors claim that the impact of the tasks of different types on the reaction time was subdued by the specifications of the task which were usual and known in advance (Zuoziene et al., 2005).

Researchers suggest that it is rather difficult to combine movement speed and accuracy because when the movement is performed faster, its duration decreases together with the possibilities of its correction (Schmidt, Lee, 1999). Analyzing the indices of maximal movement speed in the tasks of speed and accuracy we found that maximal speed value in the task of speed was $62.5 \%$ greater than performing a complicated accuracy task. Similar differences in dynamic and kinematic results were determined by other authors (Brouwer et al., 2001; Lewis et al., 2002) as well.

The complexity of the task makes a greater impact on the dispersion of movement speed results compared to the reaction time results. Dispersion of variants is considered to be low if the coefficient of variation amounts from 0 to $10 \%$, average - form 10 to $20 \%$, and high - more than $20 \%$ (Gonestas, Strielčiūnas, 2003). The highest coefficient of variation was received from the indices of movement speed performing a simple task (23\%), and the lowest - of reaction time performing a simple task $(10 \%)$. The obtained results confirm other authors' suggestion that performing a complicated task the reaction time is a more steadily controlled index than maximal movement speed (Zuozienè et al., 2005). However, this can be due to the fact that performing the speed task the repetitions were fewer compared to the tasks of reaction and accuracy.

A strong correlation was determined between the reaction time values performing the tasks of reaction and accuracy, but there was no statistical link between the maximal speed values performing the tasks of speed and accuracy. This indicates that if the movement speed is high performing a simple task, it does not mean that it will be high performing a complicated task. We suppose that this is determined by different physiological and psychological mechanisms. Reaction time is more associated with planning the task, and movement speed more depends on the speed of muscle contraction.

\section{CONCLUSIONS}

1. Performing a complicated task reaction time is longer, and maximal movement speed is lower than performing a simple task.

2. The complexity of the task more impacts the dispersion of results of the movement speed than of the reaction time.

3. High speed performing a simple task does not indicate that it will be high performing a complicated task.

\section{REFERENCES}

Allen, P. A., Murphy, M. D., Kaufman, M., Groth, K. E., Begovic, A. (2004). Age differences in central (semantic) and peripheral processing: The importance of considering both response times and errors. The Journals of Gerontology. Series B, Psychological Sciences and Social Sciences, 59 (5), 210-219.

Bernstein, N. (1967). The Co-ordination and Regulation of Movements. London: Pergamon Press.

Bootsma, R. J., Marteniuk, R. G., MacKenzie, C. L., Zaal, F. T. (1994). The speed-accuracy trade-off in manual prehension: Effects of movement amplitude object size and object width on kinematic characteristics. Experimental Brain Research, 98 (3), 535-541.

Brouwer, B., Sale, M. V., Nordstrom, M. A. (2001). Asymmetry of motor cortex excitability during a simple motor task: Relationships with handedness and manual performance. Experimental Brain Research, 138 (4), 467-476.

Davids, K., Bennet, S., Newell, K. (2006). Movement Systems Variability. Champaign, Illinois: Human Kinetics.

Fischer, M. H., Pratt, J., Adam, J. J. (2007). On the timing of reference frames for action control. Experimental Brain Research, 183 (1), 127-132.

Gignac, G. E., Vernon, P. A. (2004). Reaction time and the dominant and non-dominant hands: An extension of
Hick's Law. Personality and Individual Differences, 36, $733-739$.

Goldberger, A. L., Amaral, A. N., Hausdorff, J. M. et al. (2002). Fractal dinamics in physiology: Alterations with disease and aging. Proceedings of the National Academy of Sciences of the United States of America, 99, 1, $2466-2472$.

Gonestas, E., Strielčiūnas, R. (2003). Taikomoji statistika: vadovèlis kūno kultūros ir sporto specialybiu studentams (bakalaurams, magistrantams) bei doktorantams. Kaunas: LKKA.

Jensen, A. (1998). The G factor: The Science of Mental Ability. Westport: Praeger.

Kaplan, D., Glass, L. (1995). Understanding Nonlinear Dynamics. New York: Springer Verlag.

Kauffman, S. (1995). At home in the Universe. The Search for the Laws of Self-Organization and Complexity. New York: Oxford Univerity Press.

Kelso, J. A. S. (1999). Dynamic Patterns: The Self-Organization of Brain and Behavior. Cambridge: MIT Press.

Latash, M. L. (1998). Neurophysiological Basis of Movement. Champaign, Illinois: Human Kinetics.

Lewis, S. R., Duff, S. V., Gordon, A. M. (2002). Manual asymmetry during object release under varying task cons- 
traints. The American Journal of Occupational Therapy, 56 (4), 391-401.

Muckus, K. (2003). Psichomotorinès reakcijos ir jos komponentų priklausomybè nuo judejjimo užduoties sunkumo. Ugdymas. Küno kultūra. Sportas, 4 (49), 35-40.

Newell, K. M., Corcos, D. M. (1993). Variability and Motor Control. Champaign, Illinois: Human Kinetics.

Newell, K. M. (2003). Schema theory: Retrospectives and prospectives. Research Quarterly for Exercise and Sport, 74 (4), 383-388.

Plamondon, R., Alimi, A. M. (1997). Speed / accuracy trade-offs in target-directed movements. Behavioral and Brain Sciences, 20 (2), 279-349.

Pratt, J., Adam, J. J., Fischer, M. H. (2007). Visual layout modulates Fitt's law: The importance of first and last position. Psychonomic Bulletin \& Review, 14 (2), 350-355.

Schmidt, R. A., Lee, T. D. (1999). Motor Control and Learning: A Behavioral Emphasis. Champaign, Illinois: Human Kinetics.
Scott, S. H. (2005). Conceptual frameworks for interpreting motor cortical function: New insights from a planar multiple-joint paradigm. In A. Riehle, E. Vaadia (Eds.), Motor Cortex in Voluntary Movements. London: CRC Press. P. $157-180$.

Shen Yin-Chen, Franz, E. A. (2005). Hemispheric competition in left-handers on bimanual reaction time tasks. Journal of Motor Behavior, 37 (1), 3-9.

Skurvydas, A., Mamkus, G. (2002). Kodèl negalima tiksliai prognozuoti motorinès sistemos elgesio? Sporto mokslas, 1 (19), 14-16.

Wolpert, D. M., Ghahramani, Z., Flanagan, J. R. (2001). Perspectives and problems in motor learning. Trends in Cognitive Sciences, 5 (11), 487-494.

Zuozienè, I. J., Skurvydas, A., Mickevičienè, D. et al. (2005). The analysis of the military's arm psychomotor properties using the analyzer DPA-1. Ugdymas. Küno kultūra. Sportas, 4 (58), 67-73.

\title{
KAIP REAKCIJOS LAIKAS IR JUDESIŲ GREITIS PRIKLAUSO NUO UŽDUOTIES SUDE்TINGUMO?
}

\author{
Dalia Mickevičienė, Kristina Motiejūnaitė, Albertas Skurvydas, \\ Tomas Darbutas, Diana Karanauskienė \\ Lietuvos kūno kultūros akademija, Kaunas, Lietuva
}

\section{SANTRAUKA}

Tyrimo tikslas - nustatyti, kaip reakcijos laikas ir judesio greitis priklauso nuo užduoties sudètingumo.

Tyrimai atlikti Lietuvos kūno kultūros akademijos (LKKA) Judesių valdymo laboratorijoje naudojant žmogaus rankų ir kojų judesių dinaminių parametrų analizatorių (DPA-1) (patento Nr. 5251; 200508 25), skirtą kokybiniams vienos rankos, kojos tikslinio judesio, dviejų rankų, kojų koordinuotų ar nepriklausomų tiksliniu judesių dinaminiams parametrams išmatuoti. Buvo registruojamas 20 sveikų vyrų ir moterų dešinès rankos reakcijos laikas (RT) ir judesio greitis $\left(\mathrm{V}_{\max }\right)$ atliekant reakcijos, greitumo ir tikslumo užduotis.

Rezultatų analizè parodè, kad atliekant sudètingą užduotị reaguojama lèčiau, o maksimalus judesio greitis yra mažesnis nei atliekant paprastą užduotị. Judesio greitis bus didesnis tuomet, kai bus greičiau reaguojama atliekant paprastą užduotị. Gauti duomenys patvirtina Hicko dèsni, kuris teigia, kad reakcijos laikas yra tiesiog proporcingas užduoties sudètingumui — atliekant skirtingo sudètingumo užduotis dešinès rankos judesio reakcijos laikas statistiškai patikimai skyrèsi $(\mathrm{p}<0,001)$.

Atlikus variacijos koeficientų analizę nustatyta, kad didžiausias variacijos koeficientas yra maksimalaus judesio greičio rodiklių, atliekant greitumo užduotị (23\%), mažiausias - reakcijos laiko, atliekant reakcijos užduoti (10\%). Gauti rezultatai patvirtina kitų autorių teigini, kad atliekant sudėtingą užduotị reagavimo laikas yra patikimiau valdomas rodiklis nei maksimalusis judesio greitis.

Nustatytas stiprus koreliacinis ryšys tarp reakcijos laiko atliekant reakcijos ir tikslumo užduotis, tačiau tarp maksimalaus judesio greičio, atliekant greitumo ir tikslumo užduotis, statistinio ryšio neaptikta. Vadinasi, didelis judesio greitis atliekant paprastą užduoti dar nerodo, kad jis toks bus atliekant ir sudètingą užduotį.

Išvados: 1) atliekant sudètingą užduotị reakcijos laikas yra ilgesnis, o maksimalus greitis mažesnis nei atliekant paprastą užduoti; 2) kuo sudètingesnè užduotis, tuo jos atlikimo greitis didesnis, o reakcijos laikas nekinta; 3) didelis greitis atliekant paprastą užduotị nerodo, kad jis toks bus ir atliekant sudètingą užduoti.

Raktažodžiai: reakcijos laikas, judesių greitis, užduoties sudètingumas.

Gauta 2008 m. kovo 7 d.

Received on March 7, 2008

Priimta $2008 \mathrm{~m}$. birželio $18 \mathrm{~d}$.

Accepted on June 18, 2008
Dalia Mickevičienè

Lithuanian Academy of Physical Education

(Lietuvos kūno kultūros akademija)

Sporto str. 6, LT-44221 Kaunas

Lithuania (Lietuva)

Tel +370 37302645

E-mail d.mickeviciene@lkka.lt 